\title{
THE GENERA APOMATUS AND PROTULA (POLYCHAETA, SERPULIDAE)
}

\author{
By Jean Hanson \\ Bedford College, University of London
}

(Text-fig. I)

During an investigation of the blood systems of serpulids I have found that the pattern of the superficial blood vessels on the ventral surface of the thorax of the larger forms is a useful character for distinguishing the different genera, and sometimes is a reliable feature for distinguishing between the different species of a genus (e.g. Serpula and Protula). These blood vessels can easily be seen in living animals and are also visible in formalin-preserved specimens. Details of this matter will be published elsewhere.

Meanwhile, I wish to comment on the taxonomy of the genera Apomatus and Protula. The four western European species of these genera were obtained in the Gulf of Naples, and it was found that Apomatus ampulliferus Philippi, A. similis Marion and Bobretzky, and Protula tubularia (Montagu) all have the same type of superficial ventral thoracic blood system, whereas $P$. intestinum (Lamarck) is strikingly different in this respect. In P. intestinum (Fig. IA) the trans-septal vessels ( $t s v)$ extend over the surface of the thorax and join the ventral vessel (vv); the vessels supplying the postero-ventral flange ( $p v f)$ of the thoracic membrane $(\mathrm{tm})$ arise from the ventral vessel; the ventral vessel gives off other small vessels on to the surface of the thorax. In P. tubularia, Apomatus similis and $A$. ampulliferus (Fig. I, B, C, D) the trans-septal vessels enter two ventro-lateral vessels ( $v l v$ ) which terminate posteriorly in the flange of the thoracic membrane; the superficial blood system does not communicate with the ventral vessel. When specimens of these three species are handled they give off a strong odour which has never been encountered in P. intestinum; it resembles a mixture of machine-oil, oranges and iodine.

By taxonomists (e.g. Fauvel, 1927) the two genera are separated from each other by the presence of opercula in Apomatus and their absence in Protula. The most reliable feature distinguishing respectively Apomatus similis from A. ampulliferus and Protula intestinum from $P$. tubularia is the shape of certain adbominal chaetae. However, Apomatus similis has the same type of abdominal chaetae as Protula tubularia, and Apomatus ampulliferus has the same type of abdominal chaetae as Protula intestinum. The branchial crowns of these four species are readily autotomized when the animals are handled. When the crown with its opercula is lost Apomatus similis is indistinguishable from Protula tubularia; but the characteristic blood system of $P$. intestinum makes it easy to 
distinguish from Apomatus ampulliferus. On two occasions I have found apparently intact specimens of $A$. ampulliferus without opercula. They were distinguishable from Protula tubularia by their abdominal chaetae and from $P$. intestinum by their ventral thoracic blood systems. Thus it seems necessary to reconsider the validity of using the operculum as the diagnostic character for separating the operculate genus Apomatus from the non-operculate genus Protula.

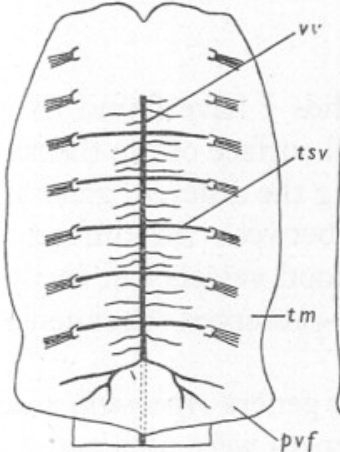

A

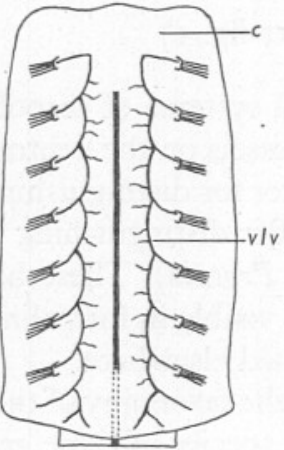

B

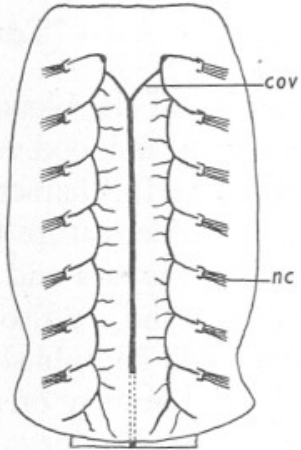

C

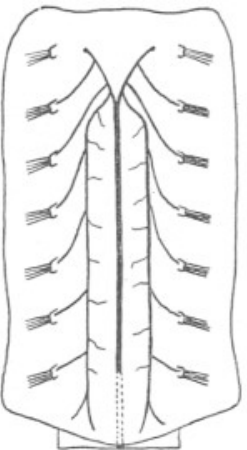

D

Fig. I. Diagrams of superficial blood vessels on ventral surface of thorax. The collar has been turned forward. A, Protula intestinum; B, P. tubularia; C, Apomatus similis; D, A. ampulliferus. c, collar; cov, circum-oesophageal vessel; $n c$, notopodial chaetae; $p v f$, postero-ventral flange of thoracic membrane; tm, thoracic membrane; $t s v$, transseptal vessel; vlv, ventro-lateral vessel; $v v$, ventral vessel.

The serpulid operculum and its peduncle represent a modified branchial filament. As Zeleny (1905) has shown, the existing serpulids can be arranged in a series reflecting the probable course of evolution of the operculum and its peduncle.

(i) Forms such as Protula without an operculum.

(ii) Salmacina dysteri with swollen tips to all its filaments. (Faulkner (1930) found that in her material the tips of the filaments were variable, some, none or all being swollen.) Similar swollen tips are noticeable on the filaments of the operculate species Vermiliopsis infundibulum (Philippi) and of the sabellid fasmineira candela (Grube).

(iii) Forms such as Filograna implexa with two equally well-developed opercula, and Apomatus with a functional and a reserve operculum, all borne by filaments which in all other respects are just like nonoperculate filaments.

(iv) Forms like Pomatoceros and Hydroides with one operculum, or with a functional and a reserve operculum borne by peduncles which are devoid of pinnules. 
This series suggests that in the genera Apomatus and Filograna the filaments bearing opercula are in the process of evolving from ordinary branchial filaments. Hence less importance should be attached to the presence or absence of an operculum in the genera at the base of the series (Protula, Apomatus, Salmacina, Filograna) than in the genera later in the series (the rest of the serpulids). In the latter group of serpulids differences in opercular structure are accompanied by differences in other features and the opercula can satisfactorily be used for distinguishing genera. Within the former group of serpulids, however, Apomatus closely resembles Protula, and Filograna closely resembles Salmacina in most features, except that Apomatus and Filograna possess opercula whilst Protula and Salmacina do not. I suggest that a more natural scheme of classification would be obtained by combining Apomatus and Protula into one genus, and Filograna and Salmacina into another genus.

I suggest also that the genera Apomatus and Protula should be revised to reflect the close similarity between $P$. tubularia and the two species of Apomatus, and the dissimilarity of Protula intestinum. Fauvel (1927) has already commented on the similarity of Apomatus similis and Protula tubularia and has suggested that the former might be a young form of the latter. On the French coast (Fauvel, 1927) Apomatus similis is smaller than Protula tubularia; at Naples also this was usually so, but I found two specimens of Apomatus similis of the same size as Protula tubularia. ${ }^{1}$

The taxonomy of Salmacina and Filograna is similarly in need of revision. Faulkner (1930) has noticed operculum-like swellings at the tips of some or all of the non-operculate filaments of some specimens of F. implexa and Salmacina dysteri, and has agreed with McIntosh (1922-23) that the separation of the operculate genus Filograna from the non-operculate genus Salmacina is unsatisfactory, because in other respects they are closely similar. Faulkner considers that Filograna implexa and Salmacina incrustans are identical except that the former possesses opercula. According to Fauvel (1927), Filograna is bisexual, thus differing from Salmacina which may be hermaphrodite; but Faulkner has found hermaphrodite specimens of Filograna implexa.

I wish to thank the staff of the Zoological Station of Naples, the British. Association for the Advancement of Science for the use of its Table, and the University of London for a grant towards travelling expenses.

\section{SUMMARY}

It is suggested that the genera Apomatus and Protula should be revised to reflect the close similarity between $P$. tubularia and the two species of Apomatus, and the dissimilarity of Protula intestinum. It is further suggested

${ }^{1}$ McIntosh (1922-23) suggests that there is only one species of Apomatus (A. ampulliferus) and only one species of Protula (P. tubularia). 
that the presence or absence of an operculum is not a sufficiently important character for distinguishing Apomatus from Protula, or Filograna from Salmanica; and therefore that these two pairs of genera should be fused into two genera.

\section{REFERENCES}

FAULKNER, G. H., 1930. The anatomy and the histology of bud-formation in the serpulid Filograna implexa. Fourn. Linn. Soc. (Zool.), Vol. xxxvII, pp. I09-90. Fauvel, P., I927. Polychètes sédentaires. Faune de France, I6. Paris.

McIntosh, W. C., I922-23. British Marine Annelids, Vol. rv. Ray Society, London. ZeLENY, C., I905. Compensatory regulation. F. Exp. Zool., Vol. II, pp. I-IO2. 